\title{
molecules
}

ISSN 1420-3049

www.mdpi.com/journal/molecules

Article

\section{Synthesis, Structure and Antioxidant Activity of Cyclohexene-Fused Selenuranes and Related Derivatives}

\section{Poonam Rajesh Prasad ${ }^{1}$, Harkesh B. Singh ${ }^{1, *}$ and Ray J. Butcher ${ }^{2}$}

1 Department of Chemistry, Indian Institute of Technology Bombay, Powai, Mumbai 400076, India;

E-Mail: poonam@chem.iitb.ac.in

2 Department of Chemistry, Howard University, Washington, DC 20059, USA;

E-Mail: rbutcher99@yahoo.com

* Author to whom correspondence should be addressed; E-Mail: chhbsia@chem.iitb.ac.in;

Tel.: +91-22-2576-7190; Fax: +91-22-2576-7152.

Academic Editor: Thomas G. Back

Received: 30 April 2015 / Accepted: 6 July 2015 / Published: 13 July 2015

\begin{abstract}
Synthesis, structure and antioxidant activity of new cyclohexene-fused spiroselenuranes and a spirotellurane is reported. Oxidation reactions of bis $(o$-formylcyclohex1-ene)selenide/bis(2-hydroxymethylcyclohex-1-ene)selenide provide the corresponding spiroselenuranes. The glutathione peroxidase-like activity of the newly synthesized compounds has been evaluated.
\end{abstract}

Keywords: spirodioxychalcogenuranes; glutathione peroxidase (GPx); antioxidant; monochalcogenides; Se-O linkage

\section{Introduction}

The biochemistry of selenium is of considerable current interest due to the discovery of selenocysteine in a number of enzymes. The enzymes include glutathione peroxidase [1,2], iodothyronine deiodinase [3-5], and thioredoxin reductase etc. [6,7]. Glutathione peroxidase (GPx) functions as an antioxidant and is responsible for the destruction of harmful peroxides in various living organisms. The enzyme's catalytic cycle involves selenol (Enz-SeH) as the active form that reduces hydroperoxides and becomes oxidized to the selenenic acid $(\mathrm{ESeOH})$, which reacts with reduced glutathione $(\mathrm{GSH})$ to form selenenyl sulfide adduct (ESeSG). A second molecule of glutathione then regenerates the active sites of the enzyme by 
attacking the selenosulfide (ESeSG) to form the oxidized glutathione (GSSG). Thus, in the overall catalytic cycle, two equivalents of glutathione are oxidized to the disulfide and water, while the hydroperoxide is reduced to the corresponding alcohol (Scheme 1) [8,9].

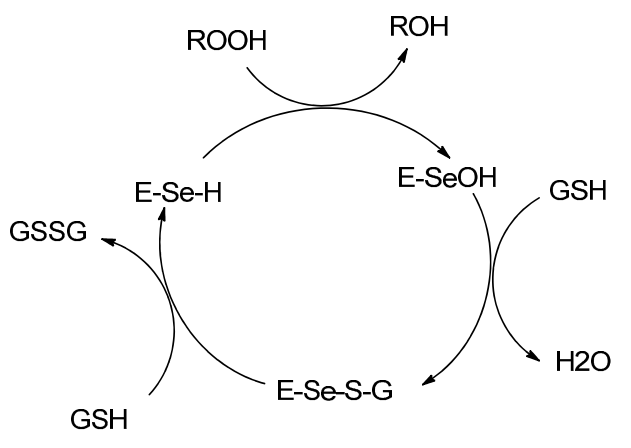

Scheme 1. Catalytic mechanism of GPx enzyme.

Recently, a series of organoselenium and -tellurium compounds which exhibit promising GPx-like antioxidant activity have been reported in the literature [10-16]. The compounds have either Se $\cdots \mathrm{O} / \mathrm{N}$ intramolecular interaction or Se-O/N linkage. The weak intramolecular interactions $(\mathrm{Se} \cdots \mathrm{N} / \mathrm{O})$ play an important role in stabilizing unstable organoselenium/-tellurium compounds and modulating the GPx-like activity of enzyme mimetics [17-19]. The important mimetics with $\mathrm{Se}-\mathrm{O} / \mathrm{Se} \mathrm{C}^{\mathrm{O}} \mathrm{O}$ include; selenide 1 [20], cyclic seleninate ester $\mathbf{2}$ [21], diselenide $\mathbf{3}$ with intramolecular interaction [22], spirodioxychalcogenuranes 4-5 [23] and 6-9 and related compounds with Se-O linkage [24-27].

Back and coworkers reported the synthesis of a series of substituted aromatic spirocycles. The methoxy-substituted selenurane (9f) proved the most effective catalyst for the reduction of hydrogen peroxide with benzyl thiol. Detailed GPx-like activity of related spirodiazaselenurane/ellurane (10-13) have been evaluated by Back and coworkers [28] and Mugesh and coworkers [29,30]. Very recently, our group reported the synthesis and structure of bicyclic diacycloxy- and diazaselenuranes 14-15 and related compounds (Figure 1) [31]. Although there are many reports on the synthesis, structural studies and GPx-like activities of aromatic spirodioxychalcogenuranes and spirodiazaselenurane/-tellurane, studies on the aliphatic analogues especially alicyclic are rare. In this paper, we report the synthesis, structural characterization of some new alicyclic spirodioxyselenuranes and a spirodioxytellurane.

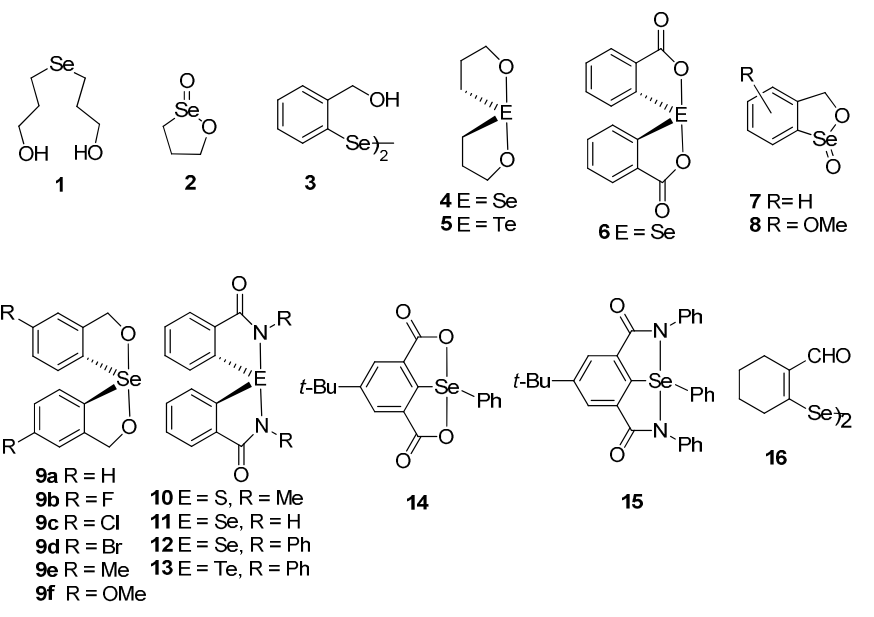

Figure 1. Some GPx mimics. 


\section{Results and Discussion}

\subsection{Synthesis}

The precursors, di-(o-formylcyclohex-1-ene)diselenide 16 (Figure 1$)$ and di-(o-formylcyclohex-1ene)selenide 17 were obtained by the disodium diselenide route [32]. Di-(o-formylcyclohex-1ene)telluride 18 was prepared by following the literature procedure [33]. Di(2-hydroxymethylcyclohex1-ene)selenide 19 was obtained by the reduction of di-(o-formylcyclohex-1-ene)selenide 17 with $\mathrm{NaBH}_{4}$. Synthesis of spirodioxychalcogenuranes 20-22 was accomplished by the oxidation of monochalcogenides 17-19 with an excess of $\mathrm{H}_{2} \mathrm{O}_{2}$ (Scheme 2).

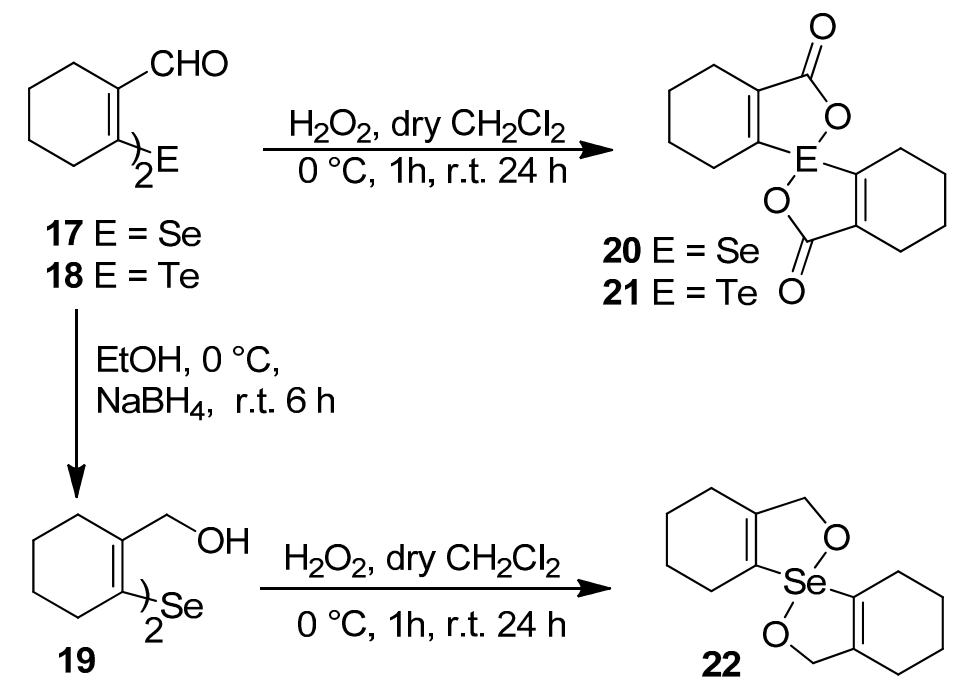

Scheme 2. Synthesis of selenide 19 and spirodioxychalcogenuranes (20-22).

\subsection{Spectroscopy Studies}

The compounds were characterized by common spectroscopic tools such as IR, ${ }^{1} \mathrm{H}-,{ }^{77} \mathrm{Se}-\mathrm{NMR}$ spectroscopy, mass spectrometry and single crystal X-ray diffraction studies (Supplementary Materials). The FT-IR spectrum of 19 exhibits the $\mathrm{OH}$ stretching frequency $(\mathrm{C}-\underline{\mathrm{OH}})$ at $3298 \mathrm{~cm}^{-1}$, indicating the presence of the alcohol group. The carbonyl stretching frequency of spirodioxyselenurane 20 and -tellurane 21 were observed at $\left(v_{\mathrm{C}=0}\right) 1683 \mathrm{~cm}^{-1} 1663 \mathrm{~cm}^{-1}$ respectively which are in good agreement with those reported for spirodioxyselenurane $6\left(1695 \mathrm{~cm}^{-1}\right)$ and 1,1'-spirobis(3H-2,1-benzoxatellurole)-3,3'-dione [34]. For compounds 19-21 the absence of the characteristic peak for the formyl group in ${ }^{1} \mathrm{H}-\mathrm{NMR}$ spectra confirmed the reduction or oxidation of 17. This was further corroborated by single crystal $\mathrm{X}$-ray analysis (vide infra). In the ${ }^{1} \mathrm{H}-\mathrm{NMR}$ spectrum of compound 22, the methylene protons $\left(-\underline{\mathrm{CH}_{2}}-\mathrm{OH}\right)$ are split. This is in contrast to the precursor 19, where these appeared as a singlet. It is due to the diastereotopic nature of the methylene protons. A similar pattern has been reported by Back and coworkers for 9a [35]. The ${ }^{77} \mathrm{Se}-\mathrm{NMR}$ spectrum of compound 22 exhibits a signal at $908 \mathrm{ppm}$. This is significantly downfield as compared to 19 (325 ppm). 


\subsection{X-ray Crystallographic Studies}

\subsubsection{Molecular Structure of $\mathbf{1 9}$}

The molecular structure of $\mathbf{1 9}$ is shown in Figure 2. The coordination geometry around the selenium atom is V-shaped with $\mathrm{C} 1 \mathrm{BA}-\mathrm{Se}-\mathrm{C} 1 \mathrm{~A}$ bond angle being $99.10(1)^{\circ}$. A distinct feature of the structure is that both the hydroxyl groups are directed away from the selenium atom and there is asymmetry in the $\mathrm{Se} \cdots \mathrm{OH}$ bond distances. The $\mathrm{Se} \cdots \mathrm{OH}$ bond distances are $3.778 \AA$ (Se-O1BA) and $4.486 \AA$ (Se-O1A), respectively. A similar observation has been made in the case of the bis(o-formylphenyl) selenide having two formyl groups trans to the selenium [36]. Selvakumar et al. also found a similar situation in the case of a (5-(tert-butyl)-2-(phenylselanyl)-1,3-phenylene)dimethanol having two hydroxyl groups where none were coordinated to the selenium [31]. However, in di(2-hydroxybenzyl)selenide [22], out of the two $\mathrm{OH}$ groups, one $\mathrm{OH}$ group was coordinated to selenium with a bond distance of $3.008 \AA$. The lack of coordinating ability of the $\mathrm{CH}_{2} \mathrm{OH}$ group in $\mathbf{1 9}$ as well as in its aromatic analogue may be due to the poor electron donating property of the $\mathrm{CH}_{2} \mathrm{OH}$ groups and the availability of rotational degrees of freedom which could prevent the $\mathrm{O} \cdots \mathrm{Se} \cdots \mathrm{O}$ repulsive interaction. The compound shows hydrogen bonding interactions between the hydroxyl groups of the adjacent molecules (Figure 3).

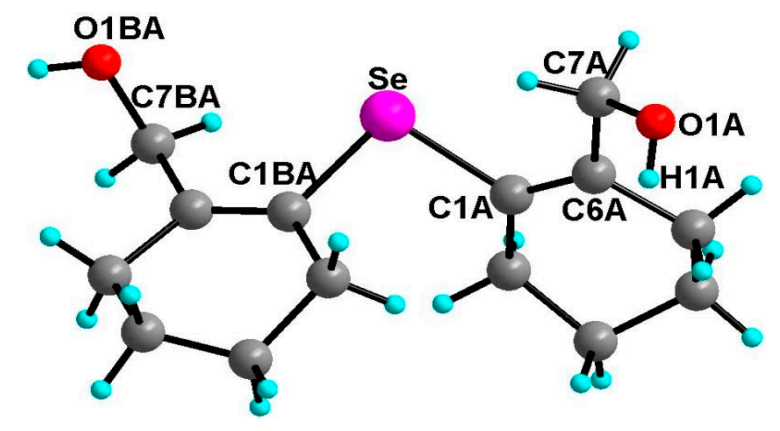

Figure 2. Molecular structure of 19. Selected bond lengths $(\AA)$ and bond angles $\left(^{\circ}\right)$; Se-C7BA-H7BA $\cdots$ Se $\quad 2.710, \quad$ C7BA-H7BA $\cdots$ Se $110.8, \quad$ C7A-H7AB $\cdots$ Se 2.704 , C7A-H7AB $\cdots$ Se 112.4, C1BA 1.935(5), Se-C1A 1.939(5), C1BA-Se-C1A 99.1(2), O1BA-C7BA-C6BA 111.8(4), O1A-C7A-C6A 114.2(4).

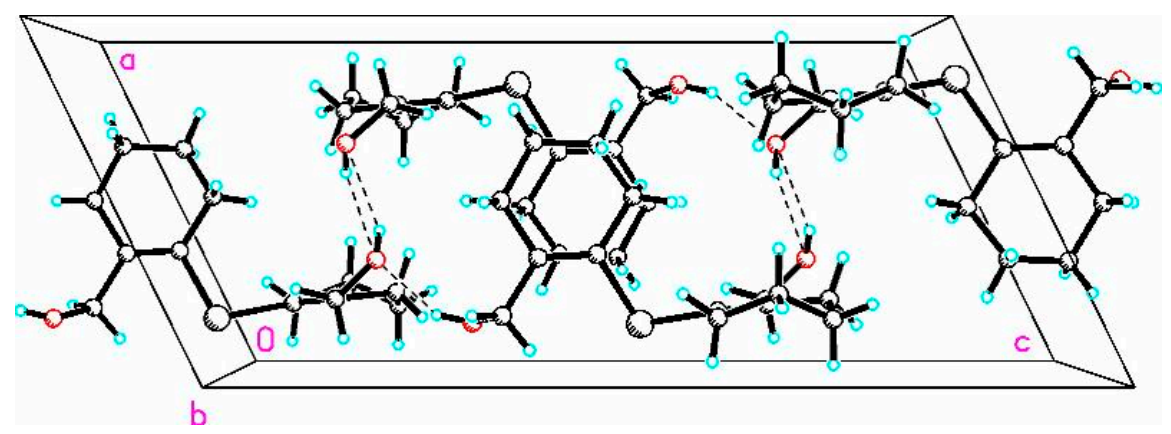

Figure 3. The short $\mathrm{OH} \cdots \mathrm{O}$ intermolecular interactions $(\mathrm{OH} \cdots \mathrm{O}, 2.163 \AA$, $\mathrm{C} 7 \mathrm{~A}-\mathrm{O} 1 \mathrm{~A} \cdots \mathrm{H} 1 \mathrm{~A} 106.3^{\circ}$ and $\mathrm{OH} \cdots \mathrm{O}, 2.040 \AA \AA$, C7A-O1A $\left.\cdots \mathrm{H} 1 \mathrm{BA} 103.1^{\circ}\right)$.

Interestingly, in case of 19, along with $\mathrm{Se} \cdots \mathrm{OH}$ intermolecular interaction, short $\mathrm{C}-\mathrm{H} \cdots \mathrm{Se}$ intramolecular interactions were also observed. The short interatomic distances between selenium and 
one of the benzylic hydrogens $(\mathrm{C}-\mathrm{H} \cdots \mathrm{Se})$ are 2.710 and $2.704 \AA$ which are shorter than the reported for diselenocin [37] (2.92 $\AA$ ) and sum of the van der Walls radii $(2.99 \AA)$ [38]. The $\mathrm{C}-\mathrm{H} \cdots$ Se bond angles for 19 are $110.8^{\circ}$ and $112.4^{\circ}$ which are good agreement with diselenocin $\left(101.7^{\circ}\right.$ and $\left.107.0^{\circ}\right)$. The solid state IR $(\mathrm{KBr})$ spectrum indicates $\mathrm{Se} \cdot \mathrm{H}-\mathrm{C}$ interaction. The $\mathrm{C}-\mathrm{H}$ symmetric stretching frequency $\left(2831 \mathrm{~cm}^{-1}\right)$ is shifted towards the lower wave number as compared with normal methylene adjacent to the electronegative atom $\left(v=2855 \mathrm{~cm}^{-1}\right)$.

To gain more information about the intramolecular $\mathrm{Se} \cdot \mathrm{H}$ interaction, density functional theory calculations have been carried out using Gaussian09 suite of programs [39]. The geometry of 19 was optimized at B3LYP/6-31+g(d) basis set. The Natural Bond Orbital (NBO) second-order perturbation energies for the $\mathrm{C}-\mathrm{H} \cdots \mathrm{Se}$ interaction for 19 are $E_{\mathrm{C}-\mathrm{H} \cdots \mathrm{Se}} 2.49$ and $1.40 \mathrm{kcal} \mathrm{mol}^{-1}$. It was further confirmed by Atoms in Molecules (AIM) analysis. The AIM [40-42] analysis was performed with AIM [43] at B3LYP/6-31+g(d) level of theory with wtbs basis set for Se and 6-31+g(d) level for remaining atoms. On carrying out AIM analysis of 19, the bond critical point was located in between $\mathrm{C}-\mathrm{H}-\mathrm{Se}$ which confirms the presence of $\mathrm{C}-\mathrm{H} \cdots$ Se intramolecular interaction (Figure 4). The values of electron density for $\mathrm{C}-\mathrm{H} \cdots$ Se were $(\rho) 0.0124$ and 0.0123 a.u.

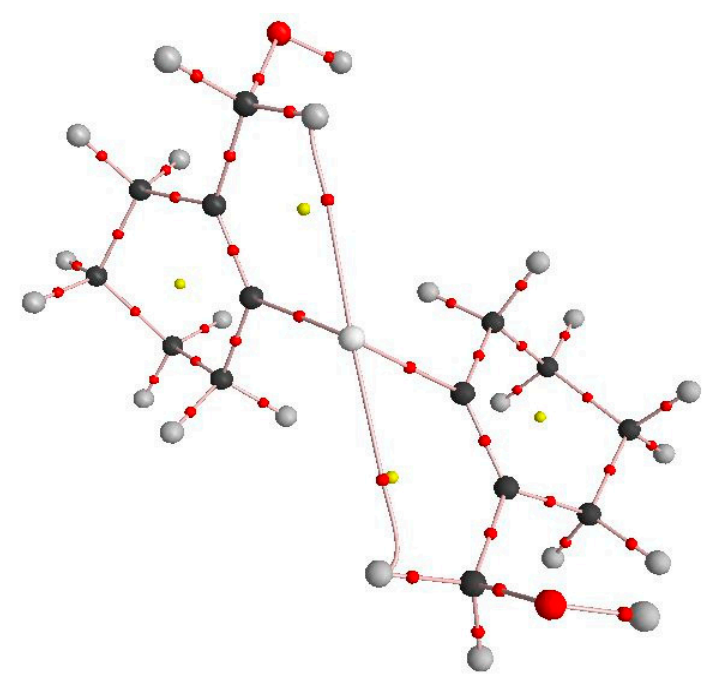

Figure 4. AIM picture of 19 showing bond critical point for $\mathrm{C}-\mathrm{H} \cdots$ Se interaction.

\subsubsection{Molecular Structure of $\mathbf{2 0}$}

Dioxyselenurane 20 crystallizes in a monoclinic crystal system with $C 2 / \mathrm{c}$ space group (Figure 5). The geometry around the central atom is distorted trigonal bipyramidal in which two Se-O bonds occupy the axial positions, two $\mathrm{Se}-\mathrm{C}$ bonds and the lone pair occupy the equatorial positions. The Se-O bond length of 1.971(1) $\AA$ is slightly elongated compared to the covalent $\mathrm{Se}-\mathrm{O}$ bond length $(1.83 \AA)$ and in good agreement with reported Se-O bond distance of 1.968(1) $\AA$ for 3,3'-spirobis(3-selenanaphthalide) [44] and significantly longer than that observed in 2-carboxylphenylmethyl selenoxide [45], $\{\mathrm{Se}-\mathrm{O}(1.774 \AA)\}$. The O1A-Se-O1A bond angle is $172.99^{\circ}$ which is deviated from the linear arrangement of $180^{\circ}$. Interestingly, the $\mathrm{O} 1 \mathrm{~A}-\mathrm{Se}-\mathrm{O} 1 \mathrm{~A}$ bond angle is equal to the reported bond angle for the aliphatic dioxaselenanonane $4\left(172.99^{\circ}\right)$ [20], and in good agreement with the reported bond angle for aromatic analogue of 3,3'-spirobis(3selenanaphthalide) $6\left(172.4^{\circ}\right)$ [44]. The dihedral angle between the planes defining the two chelate 
rings i.e., $\mathrm{O} 1 \mathrm{~A}-\mathrm{Se}-\mathrm{C} 1 \mathrm{~A}-\mathrm{C} 6 \mathrm{AC} 7 \mathrm{~A}$ and $\mathrm{Se}-\mathrm{O} 1 \mathrm{~A}-\mathrm{C} 7 \mathrm{~A}-\mathrm{C} 6 \mathrm{~A}-\mathrm{C} 1 \mathrm{~A}$ is 75.58 . The packing diagram of compound 20 shows weak intermolecular $\mathrm{O} \cdots \mathrm{Se}$ and $\mathrm{O} \cdots \mathrm{H}$ interactions with distances of 3.053(2) and 2.610(2) $\AA$, respectively to form a two dimensional supramolecular network (Figure 6). The intermolecular O2A $\cdots \mathrm{H} 3$ bond distance is $2.609(2) \AA \AA$ with bond angle $157.7(3)^{\circ}$.

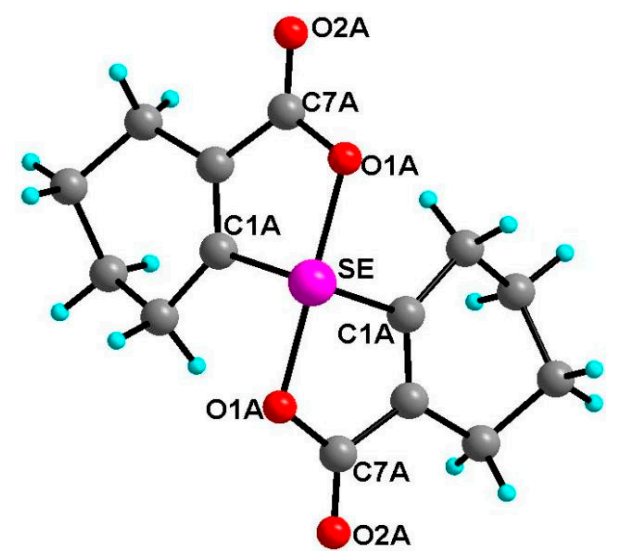

Figure 5. Molecular structure of compound 20. Selected bond lengths $(\AA)$ and bond angles $\left(^{\circ}\right)$; Se-C1A 1.939(2), Se-O1A 1.970(1), Se-O1A 1.970(1), C7A-O2A 1.213(1), C1A-Se-C1A 99.27(9), O1A-Se-O1A 172.99(7).

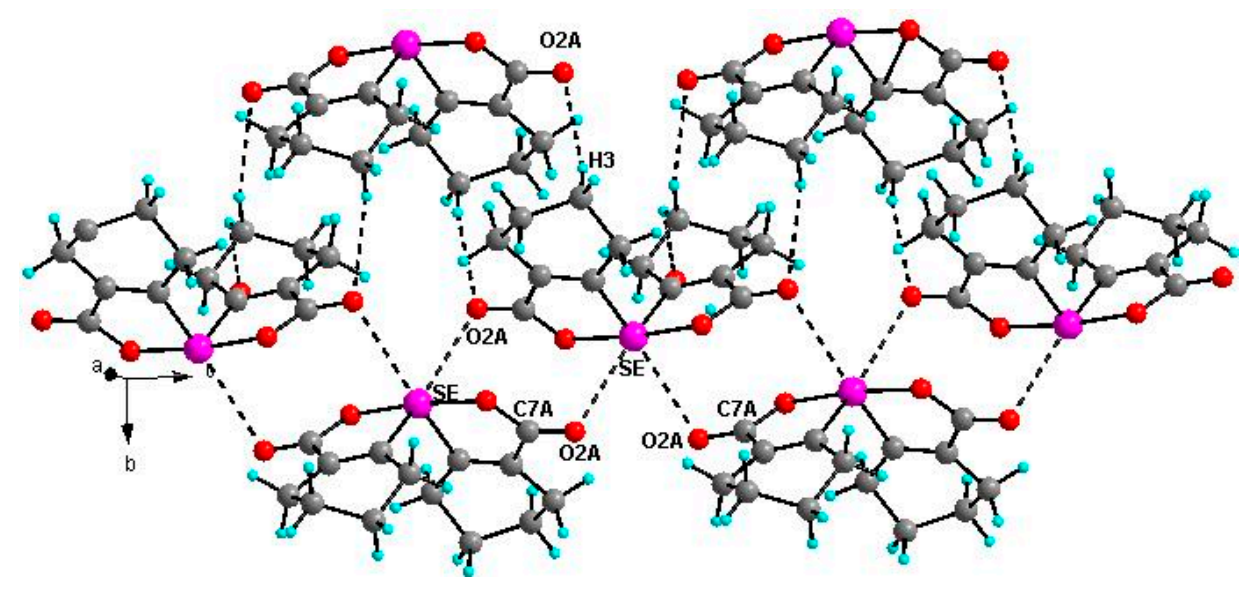

Figure 6. Two-dimensional packing diagram of compound 20 O2A $\cdots$ Se 3.053(2) $\AA$, C7A-O2A-Se 102.8(2) ${ }^{\circ}, \mathrm{O} 2 \mathrm{~A} \cdots \mathrm{H} 32.609(2) \AA, \mathrm{C} 3 \mathrm{~A}-\mathrm{H} 3-\mathrm{O} 2 \mathrm{~A} 157.7(3)^{\circ}$.

\subsubsection{Molecular Structure of $\mathbf{2 1}$}

Compound 21 (Figure 7) crystallizes in orthorhombic crystal system with Pbca space group. The geometry around the tellurium atom is distorted trigonal bipyramidal and is very similar to the selenium analogue 20 in which both Te-1OA and Te-O1B occupy the axial positions, while $\mathrm{Te}-\mathrm{C} 1 \mathrm{BA}, \mathrm{Te}-\mathrm{C} 1 \mathrm{AA}$ and the lone pair occupy the equatorial positions. The Te-O1A and Te-O1B bond lengths are 2.114(3) and 2.082(3) $\AA$, respectively. These distances are close to the sum of covalent radii of tellurium and oxygen $(2.04 \AA)$ [38]. The O1A-Te-O1B bond angle in 21 is $161.7(1)^{\circ}$ which is similar to that reported for aromatic spirotellurane $\left(161.3^{\circ}\right)$ [34]. The dihedral angles between two planes i.e., Te-C1AA-C6AA-C7A-O1A and Te-O1B-C7B-C6BA-C1BA is 77.66(21). The crystal packing diagram shows intermolecular Te $\cdots \mathrm{O}$ (carbonyl) interaction (Figure 8 ). 


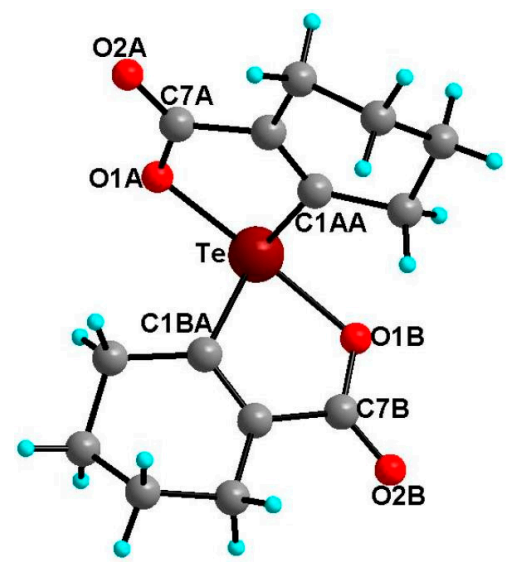

Figure 7. Molecular structure of compound 21. Selected bond lengths $(\AA)$ and bond angles $\left(^{\circ}\right)$; Te-C1AA 2.055(1), Te-C1BA 2.138(12), Te-O1A 2.114(3), Te-O1B 2.082(3), O2A-C7A 1.214(5), O2B-C7B 1.205(5), O1A-Te-O1B 161.71(1), C1AA-Te-C1BA 98.6(5).

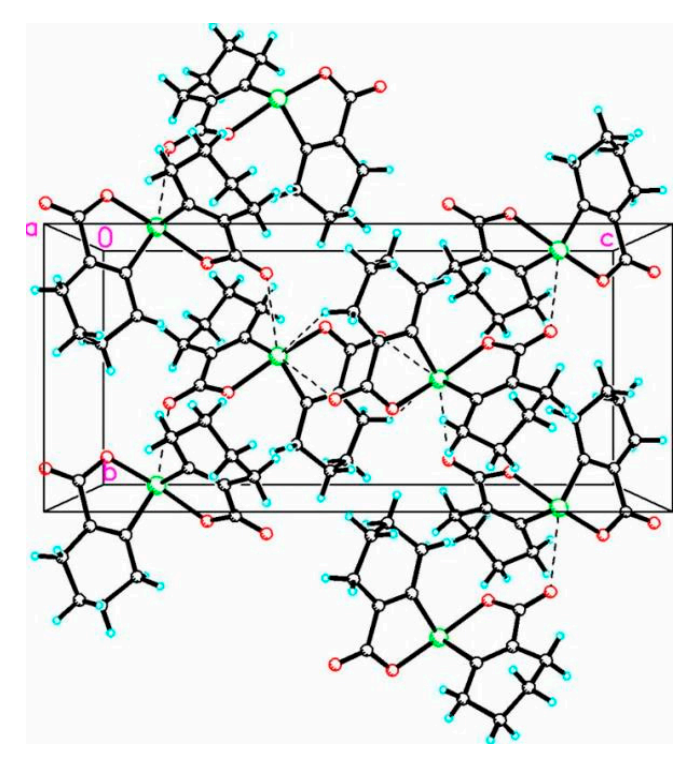

Figure 8. Two-dimensional packing diagram of compound 21. Selected bond lengths $(\AA)$ and bond angles $\left({ }^{\circ}\right)$; Te $\cdots \mathrm{O} 2 \mathrm{~A} 2.936(35) \AA$, Te $\cdots \mathrm{O} 2 \mathrm{~A}-\mathrm{C} 7 \mathrm{~A} 126.4(29)^{\circ}$.

\subsection{Glutathione Peroxidase-Like Activity}

The glutathione peroxidase activity of the compounds was determined by the coupled reductase assay [46]. In this assay, the GPx-like activity was measured by a coupled enzyme containing nicotinamide adenine dinucleotide phosphate (NADPH) $(0.01 \mathrm{M})$, glutathione (GSH) (0.05 M), catalysts $(0.002 \mathrm{M}), \mathrm{H}_{2} \mathrm{O}_{2}(0.026 \mathrm{M})$, glutathione reductase $(\mathrm{GR})\left(1.3\right.$ unit). The reduction of $\mathrm{H}_{2} \mathrm{O}_{2}$ by GSH was also recorded using ebselen for comparison. The decrease in NADPH concentration was monitored spectrophotometrically at $340 \mathrm{~nm}$ and results are summarized in Table 1. It was found that di-(o-formylcyclohex-1-ene)diselenide (16) is more efficient catalyst in comparison with ebselen, (2-phenyl-1,2-benzisoselenazol-3(2H)-one) [47], and bis(o-formylphenyl)diselenide [24]. The higher activity of $\mathbf{1 6}$ is probably due to the presence of stronger $\mathrm{Se} \cdots \mathrm{O}$ intramolecular interaction in comparison with bis(o-formylphenyl)diselenide. This stabilizes the selenenyl sulfide intermediate which in turn reacts with thiol to produce the disulfide. However, 17 and $\mathbf{1 9}$ do not show significant activity. The spirocyclic 
derivatives 20 and 22 where $\mathrm{Se}$ is in +4 oxidation state also did not show any significant activity. A similar result has been reported by Singh and co-workers [22] and Back and co-workers [23] in the case of aromatic spirocyclic derivatives. The reaction rates were similar to the control reaction rate. The GPx-like activity of compound 16 was calculated to be $\mathrm{V}_{0}=49.8 \pm 1.61 \mu \mathrm{M} \mathrm{min}^{-1}$ which is better than that of bis(o-formylphenyl)diselenide and standard ebselen (Table 1).

Table 1. Glutathione peroxidase-like activity of organoselenium compounds determined by coupled reductase assay.

\begin{tabular}{cc}
\hline Compound * & Average $\left(\mathbf{V}_{\mathbf{0}}\right) \boldsymbol{\mu} \mathbf{M} \mathbf{~ m i n}^{-\mathbf{1}}$ \\
\hline Control & $10.5 \pm 1.06$ \\
Ebselen [47] & $27.8 \pm 1.99$ \\
Bis $(o$-formylphenyl)diselenide [24] & $34.3 \pm 1.91$ \\
16 & $49.8 \pm 1.61$ \\
17 & $9.4 \pm 0.51$ \\
19 & $6.8 \pm 0.77$ \\
20 & $16.4 \pm 2.6$ \\
22 & $8.4 \pm 0.24$ \\
\hline
\end{tabular}

*: The initial rates were calculated by following the depletion of NADPH by UV method at $25{ }^{\circ} \mathrm{C}$. The reactions were carried out in $100 \mathrm{mM}$ phosphate buffer, $\mathrm{pH} 7.48$, with EDTA (1 mM), NADPH (0.01 M), GSH $(0.05 \mathrm{M})$, catalysts $(0.002 \mathrm{M}), \mathrm{H}_{2} \mathrm{O}_{2}(0.026 \mathrm{M})$, GR (1.3 unit).

\subsubsection{Mechanistic Studies on Di-(2-formylcyclohexenyl)diselenide 16}

To understand the mechanism and identify the intermediates involved in the catalytic reaction, ${ }^{77}$ Se-NMR spectroscopy has been used since its chemical shift is very sensitive to the environment. The three major intermediates involved in the peroxidase reduction, i.e., $\mathrm{RSeH}, \mathrm{RSeOH}$ and $\mathrm{RSeSPh}$, are expected to show large differences in ${ }^{77} \mathrm{Se}-\mathrm{NMR}$ chemical shift values.

\subsubsection{Reaction of 16 with PhSH Followed by TBHP}

The reaction of di-(2-formylcyclohexenyl)diselenide 16 with 3 equivalents of $\mathrm{PhSH}$ (thiophenol) does not show any new peak corresponding to the formation of the expected selenenyl sulfide $\mathbf{2 4}$ even after $30 \mathrm{~min}$. It indicates that the reactivity of $\mathrm{PhSH}$ towards $\mathbf{1 6}$ is very slow. The addition of tert-butylhydroperoxide (TBHP) to the above mixture results in the instantaneous formation of the selenenyl sulfide 24 (indicated by ${ }^{77} \mathrm{Se}-\mathrm{NMR}$ signal at $705 \mathrm{ppm}$ ). The signal is shifted downfield in comparison to the reported value of diselenide 3 (545 ppm) [22]. This significant downfield shift is due to the existence of strong $\mathrm{Se} \cdots \mathrm{O}$ intramolecular interaction in selenenyl sulfide $\mathbf{2 4}$ which suggests that $\mathbf{2 4}$ is very stable in solution and is not disproportionated to the corresponding $\mathbf{1 6}$.

\subsubsection{Reaction of Di-(2-formylcyclohexenyl)diselenide 16 with TBHP Followed by $\mathrm{PhSH}$}

In the ${ }^{77} \mathrm{Se}-\mathrm{NMR}$ spectrum, four signals at 488, 1393, 1379, and $1338 \mathrm{ppm}$ were observed for the reaction of $\mathbf{1 6}$ with two equivalents of TBHP. These correspond to diselenide 16, selenenic acid (RSeOH) 25, seleninic acid $\left(\mathrm{RSeO}_{2} \mathrm{H}\right) \mathbf{2 6}$ and selenonic acid $\left(\mathrm{RSeO}_{3} \mathrm{H}\right) \mathbf{2 7}$, respectively. Similar intermediates have been observed for the reaction of bis[2-(4,4-dimethyl-2-oxazolinyl)phenyl]diselenide [17] with $\mathrm{H}_{2} \mathrm{O}_{2}$. 
The ${ }^{77}$ Se-NMR chemical shifts are significantly downfield shifted compared with that of selenenic acid (1206 ppm), seleninic acid (1149 ppm) and selenonic (1138 ppm) formed during the reaction of (bis[2(4,4-dimethyl-2-oxazolinyl phenyl]diselenide with an excess of $\mathrm{H}_{2} \mathrm{O}_{2}$ and also downfield shifted in comparison to the selenenic acid (1200 ppm) of $\mathbf{3}$ [22].<smiles>O=CC1=C([Se])CCCC1</smiles>

$$
\begin{array}{ll}
23 X=\mathrm{H} ; & 24 X=\mathrm{SPh} \\
25 X=\mathrm{OH} ; & 26 \mathrm{X}=\mathrm{O}_{2} \mathrm{H} \\
27 \mathrm{X}=\mathrm{O}_{3} \mathrm{H} ; & 28 \mathrm{X}=(\mathrm{O}) \mathrm{SPh}
\end{array}
$$

When the reaction mixture containing TBHP was treated with seven equivalents of $\mathrm{PhSH}$, peaks corresponding to the intermediates selenenic acid 25, seleninic acid $\mathbf{2 6}$ and selenonic acid 27 disappeared. Two new peaks at 705 and 866 ppm along with peak for 16 were observed. The peaks at 705 and 866 ppm probably correspond to the selenenyl sulfide $\mathbf{2 4}$ and selenoxysulfide $\mathbf{2 8}$, respectively. Selenoxysulfide $\mathbf{2 8}$ is formed by the reaction of selenenic acid $\mathbf{2 5}$ with $\mathrm{PhSH}$. The reaction of selenenic acid with $\mathrm{PhSH}$ is analogous to the observation by Mugesh et al. [17] where bis[2-(4,4-dimethyl-2oxazolinyl)phenyl]diselenide reacts rapidly with thiol to give corresponding selenoxysulfide intermediates. After the addition of 14 equivalents of $\mathrm{PhSH}$, peaks corresponding to the $\mathbf{1 6}$ and other intermediates had disappeared except for the peak of selenenyl sulfide 24. Based on these observations and mechanisms reported for related diselenides, the following mechanism for the catalytic action of $\mathbf{1 6}$ (Scheme 3) is proposed.

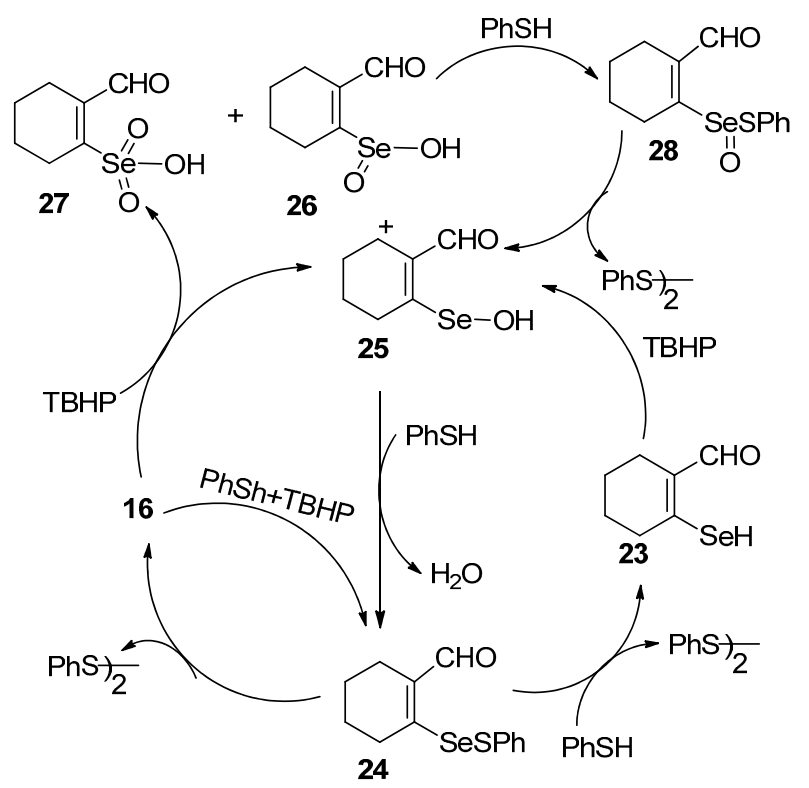

Scheme 3. GPx activity of di-(2-formylcyclohexenal)diselenide (16).

\section{Experimental Section}

\subsection{General Information}

All the organochalcogen derivatives were synthesized under nitrogen or argon atmosphere using standard Schlenk line techniques. Solvent were purified and dried by standard procedures and were freshly distilled prior to use [48]. All the chemicals used were reagent grade and were used as received. Melting points were recorded in capillary tubes. The NMR spectra were recorded in $\mathrm{CDCl}_{3}$ solvent. 
The ${ }^{1} \mathrm{H}(400 \mathrm{MHz}),{ }^{13} \mathrm{C}(100 \mathrm{MHz}),{ }^{77} \mathrm{Se}(57.26 / 76.4 \mathrm{MHz})$ and ${ }^{125} \mathrm{Te}(126.3 \mathrm{MHz})$ spectra were recorded on a Varian Mercury plus or Bruker $400 \mathrm{MHz}$ spectrometer. Chemical shifts cited were referenced with respect to TMS for $\left({ }^{1} \mathrm{H}\right.$ and ${ }^{13} \mathrm{C}$ ) as internal standard and $\mathrm{Me}_{2} \mathrm{Se}$ (for ${ }^{77} \mathrm{Se}$ ), $\mathrm{Me}_{2} \mathrm{Te}$ (for ${ }^{125} \mathrm{Te}$ ) as external standards. Elemental analysis was performed on Carlo-Erba model 1106 and Eager 300 EA112 elemental analyzers. The IR spectra were recorded in the range $400-4000 \mathrm{~cm}^{-1}$ by using $\mathrm{KBr}$ pellets for solid samples on a Thermo Nicolet Avatar 320 FT-IR spectrometer. Mass spectral (MS) studies were completed by using a QTOF Micro mass spectrometer with electrospray ionization mode analysis. In the case of isotopic patterns, the value is given for the most intense peak. The UV-VIS spectra in solution for GPx activity were recorded with a JASCO, V-570 spectrometer.

The single crystal X-ray diffraction measurements for compounds were performed on Oxford Diffraction Gemini diffraction measurement device with graphite monochromated Mo Ka radiation $(\lambda=0.7107 \AA)$. The structures were determined by routine heavy-atom method using SHELXS 97 [49] and refined by full-matrix least-squares with the non-hydrogen atom anisotropic and hydrogen atoms with fixed isotropic thermal parameters of $0.07 \AA$ by means of SHELXS 97 program [50]. The structure refinement parameters for compounds 19-21 are given in Table 2. CCDC-1041184 (19), CCDC-1041181 (20), CCDC-1041182 (21), contain the supplementary crystallographic data for this paper. These data can be obtained free of charge from The Cambridge Crystallographic Data Centre via www.ccdc.cam.ac.uk/data_request/cif.

Table 2. Crystal and structure refinement data for 19-21.

\begin{tabular}{cccc}
\hline Compound & $\mathbf{1 9}$ & $\mathbf{2 0}$ & $\mathbf{2 1}$ \\
\hline Empirical formula & $\mathrm{C}_{14} \mathrm{H}_{22} \mathrm{O}_{2} \mathrm{Se}$ & $\mathrm{C}_{56} \mathrm{H}_{64} \mathrm{O}_{16} \mathrm{Se}_{4}$ & $\mathrm{C}_{14} \mathrm{H}_{16} \mathrm{O}_{4} \mathrm{Te}$ \\
Formula weight & 301.28 & 1308.91 & 375.87 \\
Crystal system & Monoclinic & Monoclinic & Orthorhombic \\
Space group & $P 2_{1} / \mathrm{c}$ & $C 2 / \mathrm{c}$ & $P$ bca \\
$a(\AA)$ & $8.7358(12)$ & $15.0340(13)$ & $15.7046(2)$ \\
$b(\AA)$ & $9.1761(12)$ & $8.5925(7)$ & $8.83038(16)$ \\
$c(\AA)$ & $19.689(2)$ & $10.4102(8)$ & $19.1603(3)$ \\
$\alpha\left(^{\circ}\right)$ & 90 & 90 & 90 \\
$\beta\left(^{\circ}\right)$ & $116.096(8)$ & $112.358(4))$ & 90 \\
$\gamma\left(^{\circ}\right)$ & 90 & 90 & 90 \\
$V\left(\AA^{3}\right)$ & $1417.4(3)$ & $1242.69(18)$ & $2657.11(8)$ \\
$Z$ & 4 & 1 & 8 \\
$\mathrm{D}\left(\right.$ calcd) $\left(\mathrm{Mg} / \mathrm{m}^{3}\right)$ & 1.412 & 1.748 & 1.879 \\
$\mathrm{Absorption}$ coefficient $\left(\mathrm{mm}^{-1}\right)$ & 2.639 & 2.027 & 17.759 \\
Reflections collected & 7290 & 11304 & 5111 \\
Final $R(\mathrm{~F})[I>2 \sigma(I)]^{\mathrm{a}}$ & 0.0567 & 0.0237 & 0.0515 \\
$w R(\mathrm{~F} 2)$ indices $[I>2 \sigma(I)]$ & 0.1414 & 0.0597 & 0.1361 \\
Data/restraints/parameters & $2522 / 17 / 158$ & $1963 / 0 / 87$ & $2513 / 72 / 210$ \\
Goodness-of-fit on $\mathrm{F}^{2}$ & 1.024 & 1.099 & 1.032 \\
\hline a: $R(F \mathrm{o})=\sum\|F \mathrm{O}|-| F \mathrm{c}\| / \sum|F \mathrm{o}|$ and $w R\left(F \mathrm{o}^{2}\right)=\left\{\sum\left[w\left(F \mathrm{o}^{2}-F \mathrm{c}^{2}\right)^{2}\right] / \sum\left[w\left(F \mathrm{c}^{2}\right)^{2}\right\}^{1 / 2}\right.$.
\end{tabular}




\subsection{Synthesis}

Di(2-hydroxymethylcyclohex-1-ene)selenide 19. To a stirred solution of di-(2-formylcyclohexenyl)selenide $17(0.106 \mathrm{~g}, 0.34 \mathrm{mmol})$ in dry methanol $(5 \mathrm{~mL})$ was added an excess of $\mathrm{NaBH}_{4}(0.051 \mathrm{~g}, 1.36 \mathrm{mmol})$ at $0{ }^{\circ} \mathrm{C}$. The reaction mixture was stirred for $6 \mathrm{~h}$. Solvent was evaporated and the residue poured into crushed ice. The product was extracted with chloroform and the combined organic layers were washed with a saturated brine solution. It was dried over sodium sulfate and concentrated to give $\mathbf{1 9}$ as white solid.

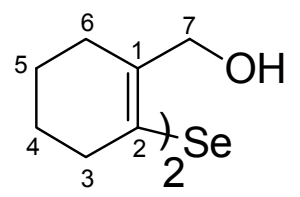

19

Yield: $0.060 \mathrm{~g}(25 \%), \mathrm{mp} 126-128{ }^{\circ} \mathrm{C}$; ${ }^{1} \mathrm{H}-\mathrm{NMR}\left(400 \mathrm{MHz}, \mathrm{CDCl}_{3}\right): \delta 4.30(\mathrm{~s}, 4 \mathrm{H}), 2.29-2.27$ (dd, 8H), 1.65-1.64 (dd, 8H); ${ }^{13} \mathrm{C}-\mathrm{NMR}\left(\mathrm{CDCl}_{3}\right): \delta 141.2$ (C1), 126.7 (C2), 66.4 (C7), 34.4 (C3), 29.4 (C6), 24.4 (C4), 22.7 (C5); ${ }^{77} \mathrm{Se}-\mathrm{NMR}\left(\mathrm{CDCl}_{3}\right): \delta$ 325. ES-HRMS: $m / z$ calcd. for $\mathrm{C}_{14} \mathrm{H}_{22} \mathrm{SeO}_{2}: 302.0785$ $[\mathrm{M}]^{+}$; found: $325.0688[\mathrm{M}+\mathrm{Na}]^{+}$. FT-IR v 1019, 1429, 1443, 2875, 2855, 2926, $3298 \mathrm{~cm}^{-1}$. Anal. Calcd. for $\mathrm{C}_{14} \mathrm{H}_{22} \mathrm{SeO}_{2}$ : C, 55.81; H, 7.36; found C, 56.18; H, 6.97.

Spirodioxyselenurane 20. To a stirred solution of di-(2-formylcyclohexenyl)selenide 17 (0.112 g, $0.34 \mathrm{mmol})$ in dry $\mathrm{CH}_{2} \mathrm{Cl}_{2}(10 \mathrm{~mL})$ was added $30 \%$ of $\mathrm{H}_{2} \mathrm{O}_{2}(120 \mu \mathrm{L}, 1.02 \mathrm{mmol})$ at $0{ }^{\circ} \mathrm{C}$. The reaction mixture was stirred for $24 \mathrm{~h}$ at room temperature to give compound $\mathbf{2 0}$ as a white solid.

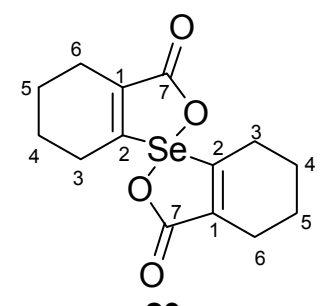

20

Yield: $0.05 \mathrm{~g}(48 \%) . \mathrm{mp} 87-89{ }^{\circ} \mathrm{C} .{ }^{1} \mathrm{H}-\mathrm{NMR}\left(400 \mathrm{MHz}, \mathrm{CDCl}_{3}\right): \delta(\mathrm{ppm}) 2.57-2.50(\mathrm{~m}, 4 \mathrm{H}), 2.39-2.38$ (m, 8H), 1.86-1.67 (m, 8H); ${ }^{13} \mathrm{C}-\mathrm{NMR}\left(\mathrm{CDCl}_{3}\right): \delta 190.3$ (C7), 150.1 (C2), 140.1 (C1), $30.5(\mathrm{C} 6), 20.5$ (C4), 20.4 (C3), 20.2 (C5); ${ }^{77} \mathrm{Se}-\mathrm{NMR}\left(\mathrm{CDCl}_{3}\right)$ : $\delta$ 801; ES-HRMS: $m / z$ calcd. for $\mathrm{C}_{14} \mathrm{H}_{16} \mathrm{SeO}_{4}$ : $328.0214[\mathrm{M}]^{+}$; found: $329.0294[\mathrm{M}+\mathrm{H}]^{+}$. FT-IR $(\mathrm{KBr}) \cup 740,759,1138,1238,1683,2941 \mathrm{~cm}^{-1}$. Anal. Calcd. for $\mathrm{C}_{14} \mathrm{H}_{16} \mathrm{SeO}_{4}$ : C, 51.39; H, 4.93; found C, 50.84; H, 4.81 .

Spirodioxytellurane 21. A solution of compound $18(0.1 \mathrm{~g}, 0.28 \mathrm{mmol})$ in dry $\mathrm{CH}_{2} \mathrm{Cl}_{2}(5 \mathrm{~mL})$ was treated with an aqueous $30 \%$ of $\mathrm{H}_{2} \mathrm{O}_{2}(99 \mu \mathrm{L}, 0.86 \mathrm{mmol})$ at $0{ }^{\circ} \mathrm{C}$. The mixture was stirred for $24 \mathrm{~h}$ at room temperature; the solvent was evaporated to give compound $\mathbf{2 1}$ as a white solid.

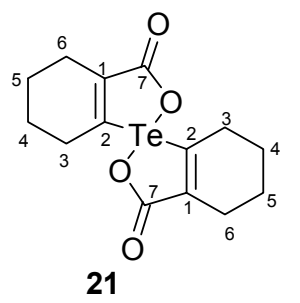


Yield: $0.09 \mathrm{~g}(25 \%), \mathrm{mp} 95-97{ }^{\circ} \mathrm{C} ;{ }^{1} \mathrm{H}-\mathrm{NMR}\left(400 \mathrm{MHz}, \mathrm{CDCl}_{3}\right): \delta(\mathrm{ppm})$ 1.84-1.74 (m, 8H), 2.76-2.23 (m, 8H); ${ }^{13} \mathrm{C}-\mathrm{NMR}\left(\mathrm{CDCl}_{3}\right): \delta 190.3$ (C7), 150.2 (C2), 140.2 (C1), 30.6 (C6), 20.5 (C3), 20.40 (C4), 20.2 (C5); ${ }^{125} \mathrm{Te}-\mathrm{NMR}\left(\mathrm{CDCl}_{3}\right): \delta$ 1088.7. ES-HRMS: $\mathrm{m} / z$ calcd. for $\mathrm{C}_{14} \mathrm{H}_{16} \mathrm{TeO}_{4}(378.0111)[\mathrm{M}]^{+}$; found $379.0174[\mathrm{M}+\mathrm{H}]^{+}$. FT-IR $(\mathrm{KBr})$ v 702, 975, 1203, 1584, 1663, 2931 $\mathrm{cm}^{-1}$. Anal. Calcd. for $\mathrm{C}_{14} \mathrm{H}_{16} \mathrm{TeO}_{4}$ : C, 44.74; H, 4.29; found $\mathrm{C}, 45.02 ; \mathrm{H}, 5.38$.

Spirodioxyselenurane 22. To a solution of selenide $19(0.1 \mathrm{~g}, 0.28 \mathrm{mmol})$ in dry $\mathrm{CH}_{2} \mathrm{Cl}_{2}(5 \mathrm{~mL})$ was added an aqueous $30 \%$ of $\mathrm{H}_{2} \mathrm{O}_{2}(99 \mu \mathrm{L}, 0.86 \mathrm{mmol})$ at $0{ }^{\circ} \mathrm{C}$. The resultant mixture was stirred for $24 \mathrm{~h}$ at room temperature, the solvent was evaporated to afford 22 as a white solid.

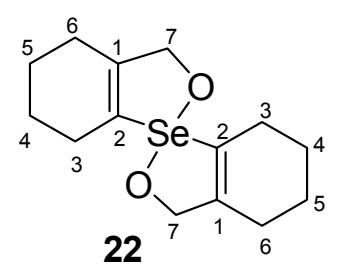

Yield: $0.07 \mathrm{~g} \mathrm{(49 \% ).} \mathrm{mp} \mathrm{82-84}{ }^{\circ} \mathrm{C} .{ }^{1} \mathrm{H}-\mathrm{NMR}\left(400 \mathrm{MHZ}, \mathrm{CDCl}_{3}\right): \delta(\mathrm{ppm}) 4.66-4.55\left(\mathrm{~d}, 4 \mathrm{H},{ }^{2} \mathrm{~J}=12 \mathrm{~Hz}\right)$, 2.52-2.06 (m, 8H), 1.77-1.67 (m, 8H); ${ }^{13} \mathrm{C}-\mathrm{NMR}\left(\mathrm{CDCl}_{3}\right): \delta ; 144.3(\mathrm{C} 2), 131.9(\mathrm{C} 1), 76.1$ (C7), 25.5 (C6), 25.3 (C4), 24.3 (C5), 21.5 (C3); ${ }^{77} \mathrm{Se}-\mathrm{NMR}\left(\mathrm{CDCl}_{3}\right)$ : $\delta$ 908; ES-HRMS: $\mathrm{m} / \mathrm{z}$ calcd. for $\mathrm{C}_{14} \mathrm{H}_{20} \mathrm{SeO}_{2}: 300.0629,[\mathrm{M}]^{+}$; found: $301.0705[\mathrm{M}+\mathrm{H}]^{+}$. Anal. Calcd. for $\mathrm{C}_{14} \mathrm{H}_{20} \mathrm{SeO}_{2}$ : C, 56.19; $\mathrm{H}$, 5.74; found C, 50.60; H, 5.99.

\subsection{Coupled Reductase Assay}

The GPx-like activities of 16-20 were measured by JASCO spectrophotometer according to the literature method using ebselen as the standard. The catalytic reaction was carried out at room temperature $\left(25^{\circ} \mathrm{C}\right)$ in $1 \mathrm{~mL}$ of the solution containing $100 \mathrm{mM}$ potassium phosphate buffer, $\mathrm{pH} 7.5,1 \mathrm{mM}$ EDTA, $0.1 \mathrm{mM} \mathrm{GSH}, 0.25 \mathrm{mM}$ of NADPH, $0.020 \mathrm{mM}$ of catalyst and $0.26 \mathrm{mM}$ of $\mathrm{H}_{2} \mathrm{O}_{2}$. The activity was followed by the decrease of NADPH on addition of $\mathrm{H}_{2} \mathrm{O}_{2}$ and absorption was measured at $340 \mathrm{~nm}$ $\left(\varepsilon_{\max }=6.22 \times 10^{3} \mathrm{M}^{-1} \mathrm{~cm}^{-1}\right)$ (chemical reactions (1)-(3)). Each of the experiments was carried out in triplicate.

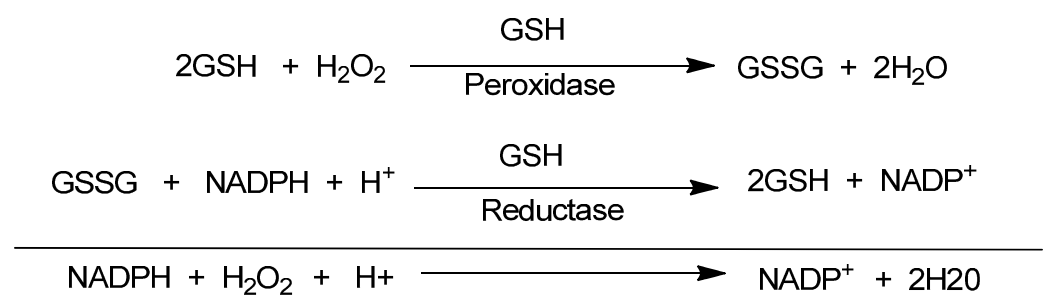

\section{Conclusions}

Di-(2-formylcyclohexenyl)diselenide 16 showed better GPx like activity than the aromatic analogue bis(o-formylphenyl)diselenide whereas di(2-hydroxymethylcyclohex-1-ene)selenide 19 and spirodioxyselenurane $\mathbf{2 0}$ and $\mathbf{2 2}$ did not show any significant activity. 


\section{Supplementary Materials}

Supplementary materials can be accessed at: http:/www.mdpi.com/1420-3049/20/07/12670/s1.

\section{Acknowledgments}

H.B.S. is grateful to the Department of Science and Technology (DST), New Delhi (India), for generous funding. P.R.P. is thankful to Department of Chemistry, IIT Bombay for a teaching assistantship.

\section{Author Contributions}

All the authors have contributed equally.

\section{Conflicts of Interest}

The authors declare no conflict of interest.

\section{References}

1. Epp, O.; Ladenstein, R.; Wendel, A. The refined structure of the selenoenzyme glutathione peroxidase at 0.2-nm resolution. Eur. J. Biochem. 1983, 133, 51-69.

2. Arthur, J.R.; Beckett, G.J. Roles of selenium in type I iodothyronine 5'-deiodinase and in thyroid hormone and iodine metabolism. In Selenium in Biology and Human Health; Burk, R.F., Ed.; Springer-Verlag: New York, NY, USA, 1994.

3. Berry, M.J.; Banu, L.; Larsen, P.R. Type I iodothyronine deiodinase is a selenocysteinecontaining enzyme. Nature 1991, 349, 438-440.

4. Behne, D.; Kyriakopoulos, A.; Meinhold, H.; Köhrle, J. Identification of type I iodothyronine 5'-deiodinase as a selenoenzyme. Biochem. Biophys. Res. Commun. 1990, 173, 1143-1149.

5. Bianco, A.C.; Salvatore, D.; Gereben, B.; Berry, M.J.; Larsen, P.R. Biochemistry, cellular and molecular biology, and physiological roles of the iodothyronine selenodeiodinases. Endocr. Rev. 2002, 23, 38-89.

6. Lee, S.-R.; Kim, J.-R.; Kwon, K.-S.; Yoon, H.W.; Levine, R.L.; Ginsburg, A.; Rhee, S.G. Molecular cloning and characterization of a mitochondrial selenocysteine-containing thioredoxin reductase from rat liver. J. Biol. Chem. 1999, 274, 4722-4734.

7. Williams, C.H., Jr.; Arscott, L.D.; Müller, S.; Lennon, B.W.; Ludwig, M.L.; Wang, P.F.; Veine, D.M.; Becker, K.; Schirmer, R.H. Thioredoxin reductase two modes of catalysis have evolved. Eur. J. Biochem. 2000, 267, 6110-6117.

8. Mugesh, G.; Singh, H.B. Synthetic organoselenium compounds as antioxidants: Glutathione peroxidiseactivity. Chem. Soc. Rev. 2000, 29, 347-357.

9. Mugesh, G.; du Mont, W.W.; Sies, H. Chemistry of biologically important synthetic organoseleniumcompounds. Chem. Rev. 2001, 101, 2125-2179.

10. Nogueira, C.W.; Rocha, J.B.T. Organoselenium and organotellurium compounds: Toxicology and pharmacology. In Organic Selenium and Tellurium Compounds; Rappoport, Z., Ed.; Wiley: Chichester, UK, 2012; Volume 3, Part II, Chapter 21. 
11. Masukawa, T. Pharmacological and toxicological aspects of inorganic and organic selenium compounds. The Chemistry of Organoselenium and Tellurium Compounds; Patai, S., Ed.; Wiley: Chichester, UK, 1987; Volume 2, Chapter 9.

12. Jamier, V.; Ba, L.A.; Jacob, C. Selenium- and tellurium-containing multifunctional redox agents as biochemical redox modulators with selective cytotoxicity. Chem. Eur. J. 2010, 16, 10920-10928.

13. Bhowmick, D.; Mugesh, G. Enzyme mimetic chemistry of organoselenium compounds. In The Chemistry of Organoselenium and Tellurium Compounds; Patai, S., Ed.; Wiley: Chichester, UK, 2013; Volume 4, Part II, Chapter 16.

14. Bhabak, K.P.; Mugesh, G. Functional mimics of glutathione peroxidase: Bioinspired synthetic antioxidant. Acc. Chem. Res. 2010, 43, 1408-1419.

15. Bhuyan, B.J.; Lamani, D.S.; Mugesh, G.; Wirth, T. Current research on mimics and models of selenium-containing antioxidants. In Handbook of Chalcogen Chemistry: New Perspectives in Sulfur, Selenium and Tellurium, 2nd ed.; RSC: Cambridge, UK, 2013.

16. Mugesh, G. Glutathione peroxidase activity of ebselen and its analogues: Some insights into the complex chemical mechanisms underlying the antioxidant activity. Curr. Chem. Biol. 2013, 7, 47-56.

17. Mugesh, G.; Panda, A.; Singh, H.B.; Punekar, N.S.; Butcher, R.J. Glutathione peroxidase-like antioxidant Activity of diaryl diselenides: A mechanistic study. J. Am. Chem. Soc. 2001, 123, 839-850.

18. Mukherjee, A.J.; Zade, S.S.; Singh, H.B.; Sunoj, R.B. Organoselenium chemistry: Role of Intramolecular interactions. Chem. Rev. 2010, 110, 4357-4416.

19. Bayse, C.A.; Pavlou, A. Tuning the activity of glutathione peroxidase mimics through intramolecular Se $\cdots$ N,O interactions: A DFT study incorporating solvent-assisted proton exchange (SAPE). Org. Biomol. Chem. 2011, 9, 8006-8015.

20. Back, T.G.; Moussa, Z.; Parvez, M. The exceptional glutathione peroxidase-like activity of di(3-hydroxypropyl) selenide and the unexpected role of a novel spirodioxaselenanonane intermediate in the catalytic cycle. Angew. Chem. Int. Ed. 2004, 43, 1268-1270.

21. Back, T.G.; Moussa, Z. Remarkable activity of a novel cyclic seleninate ester as a glutathione peroxidase mimetic and its facile in situ generation from allyl 3-hydroxypropyl selenide. J. Am. Chem. Soc. 2002, 124, 12104-12105.

22. Tripathi, S.K.; Patel, U.; Roy, D.; Sunoj, R.B.; Singh, H.B.; Wolmershäuser, G.; Butcher, R.J. $o$-Hydroxylmethylphenylchalcogens: Synthesis, intramolecular nonbonded chalcogen $\cdots \mathrm{OH}$ interactions, and glutathione peroxidase-like activity. J. Org. Chem. 2005, 70, 9237-9247.

23. Back, T.G.; Kuzma, D.; Parvez, M. Aromatic derivatives and tellurium analogues of cyclic seleninate esters and spirodioxyselenuranes that act as glutathione peroxidase mimetics. J. Org. Chem. 2005, 70, 9230-9236.

24. Kumar, S.; Panda, S.; Singh, H.; Wolmershäuser, G.; Butcher, R. Structural aspects of some organoselenium compounds. Struct. Chem. 2007, 18, 127-132.

25. Press, D.J.; Mercier, E.A.; Kuzma, D.A.; Back, T.G. Substituent effects upon the catalytic activity of aromatic cyclic seleninate esters and spirodioxyselenuranes that act as glutathione peroxidase mimetics. J. Org. Chem. 2008, 73, 4252-4255.

26. Back, T.G.; Moussa, Z.J. Diselenides and allyl selenides as glutathione peroxidase mimetics. Remarkable activity of cyclic seleninates produced in situ by the oxidation of allyl ö-hydroxyalkyl selenides. J. Am. Chem. Soc. 2003, 125, 13455-13460. 
27. Press, D.J.; McNeil, N.M.R.; Hambrook, M.; Back, T.G. Effects of methoxy substituents on the glutathione peroxidase-like activity of cyclic seleninate esters. J. Org. Chem. 2014, 79, 9394-9401.

28. Kuzma, D.; Parvez, M.; Back, T.G. Formation of a spirodiazaselenurane and its corresponding azaselenonium derivatives from the oxidation of 2,2'-selenobis(benzamide). Structure, properties and glutathione peroxidase activity. Org. Biomol. Chem. 2007, 5, 3213-3217.

29. Sarma, B.K.; Manna, D.; Minoura, M.; Mugesh, G. Synthesis, structure, spirocyclization mechanism, and glutathione peroxidase-like antioxidant activity of stable spirodiazaselenurane and spirodiazatellurane. J. Am. Chem. Soc. 2010, 132, 5364-5374.

30. Lamani, D.S.; Bhowmick, D.; Mugesh, G. Spirodiazaselenuranes: Synthesis, structure and antioxidant activity. Org. Biomol. Chem. 2012, 10, 7933-7943.

31. Selvakumar, K.; Singh, H.B.; Goel, N.; Singh, U.P.; Butcher, R.J. Synthesis and structural characterization of pincer type bicyclic diacyloxy- and diazaselenuranes. Dalton Trans. 2011, 40, 9858-9867.

32. Prasad, P.R.; Singh, H.B.; Butcher, R.J. Synthesis, structure and reactivity of $\beta$-chalcocyclohexenals: dichalcogenides and chalcogenides. Dalton Trans. 2015, (submitted).

33. Minkin, V.I.; Sadekov, I.D.; Rivkin, B.B.; Zakharov, A.V.; Nivorozhkin, V.L.; Kompan, O.E.; Struchkov, Y.T. Synthesis and structure of $\beta$-tellurovinylcarbonyl compounds. J. Organomet. Chem. 1997, 536, 233-248.

34. Takaguchi, Y.; Furukawa, N. First synthesis and structural determination of 1,1'-spirobis(3H-2, 1-benzoxatellurole)-3,3'-dione ([10-Te-4(C202)]). Heteroat. Chem. 1995, 6, 481-485.

35. Press, D.J.; McNeil, N.M.R.; Rauk, A.; Back, T.G. NMR and Computational Studies of the configurational properties of spirodioxyselenuranes. Are dynamic exchange processes or temperature-dependent chemical shifts involved? J. Org.Chem. 2012, 77, 9268-9276.

36. Panda, A.; Menon, S.C.; Singh, H.B.; Butcher, R.J. Synthesis of some macrocycles:Bicycles from bis(o-formylphenyl) selenide: X-ray crystal structure of bis(o-formylphenyl) selenide and the first 28-membered selenium containing macrocyclic ligand. J. Organomet. Chem. 2001, 623, 87-94.

37. Iwaoka, M.; Tomoda, S. First observation of a C-H...Se "hydrogen bond". J. Am. Chem. Soc. 1994, 116, 4463-4464.

38. Cordero, B.; Gomez, V.; Platero-Prats, A.E.; Reves, M.; Echeverria, J.; Cremades, E.; Barragan, F.; Alvarez, S. Covalent radii revisited. Dalton Trans. 2008, 21, 2832-2838.

39. Frisch, M.J.; Trucks, G.W.; Schlegel, H.B.; Scuseria, G.E.; Robb, M.A.; Cheeseman, J.R.; Scalmani, G.; Barone, V.; Mennucci, B.; Petersson, G.A.; et al. Gaussian 09, Revision D.01; Gaussian, Inc.: Wallingford, CT, USA, 2009.

40. Bader, R.F.W. Atoms in Molecules: A Quantum Theory; Oxford University Press: New York, NY, USA, 1990.

41. Popelier, P. Atoms in molecules: An introduction; Pearson: Harlow, UK, 2000.

42. Matta, C.F.; Boyd, R.J. The Quantum Theory of Atoms in Molecules; Wiley-VCH: Weinheim, Germany, 2007.

43. Biegler-Konig, F.; Schonbohm, J.; Bayles, D. Software news and updates AIM2000-a program to analyze and visualize atoms in molecules. J. Comput. Chem. 2001, 22, 545-559.

44. Dahlén, B.; Lindgren, B. Formatin and crystal structure of 3,3'-spirobi(3-selenaphthalide). Acta Chem. Scand. 1993, 27, 2218-2220. 
45. Dahlen, B. The molecular structure of $o$-carboxyphenyl methyl sulphoxide and o-carboxyphenyl methyl selenium oxide. Acta Crystallogr. B 1973, 29, 595-602.

46. Wilson, S.R.; Zucker, P.A.; Huang, R.R.; Spector, A. Development of synthetic compounds with glotathione peroxidase activity. J. Am. Chem. Soc. 1989, 111, 5936-5939.

47. Müller, A.; Cadenas, E.; Graf, P.; Sies, H. A novel biologically active seleno-organic compound-1: Glutathione peroxidase-like activity in vitro and antioxidant capacity of PZ 51 (Ebselen). Biochem. Pharmacol. 1984, 33, 3235-3239.

48. Perrin, D.D.; Armargo, W.L.F.; Perrin, D.R. Purification of Laboratory Chemicals, 4th ed.; Pergamon Press: Oxford, UK, 1996.

49. Sheldrick, G.M. SHELXS-97, Program for Crystal Structure Solution University of Göttingen; University of Göttingen: Gottingen, Germany, 1990.

50. Sheldrick, G.M. SHELXL-97, Program for Crystal Structure Refinement; University of Göttingen: Gottingen, Germany, 1997.

Sample Availability: Samples of the compounds not available from the authors.

(C) 2015 by the authors; licensee MDPI, Basel, Switzerland. This article is an open access article distributed under the terms and conditions of the Creative Commons Attribution license (http://creativecommons.org/licenses/by/4.0/). 